SCIREA Journal of Clinical Medicine

ISSN: 2706-8870

http://www.scirea.org/journal/CM

June 8, 2021

SCIREA

Volume 6, Issue 3, June 2021

\title{
Correction of bone marrow failure in patients with polytrauma by injection of native DNA fragments (randomized prospective double-blind placebo-controlled study)
}

Ludmila Pavlovna Pivovarova1, Irina Viktorovna Osipova, ${ }^{1, *}$, Olga Borisovna Ariskin ${ }^{1}$, Mikhail Ivanovich Gromov², Aleksandr Nikolaevich Tulupov ${ }^{3}$, Aleksandr Valeryevich Nikitin $^{3}$, Vladimir Nikolaevich Lapshin ${ }^{4}$

${ }^{1}$ Laboratory Diagnostics Department, Saint Petersburg I.I. Dzhanelidze Research Institute of Emergency Medicine, Saint-Petersburg, Russia

${ }^{2}$ Department of Efferent Therapy, Saint Petersburg I.I. Dzhanelidze Research Institute of Emergency Medicine, Saint-Petersburg, Russia

${ }^{3}$ Department of Concomitant Injury, Saint Petersburg I.I. Dzhanelidze Research Institute of Emergency Medicine, Saint-Petersburg, Russia

${ }^{4}$ Department of Anesthesiology and Reanimatology, Saint Petersburg I.I. Dzhanelidze Research Institute of Emergency Medicine, Saint-Petersburg, Russia

*Corresponding author 


\begin{abstract}
:
A single-center efficacy study of sodium deoxyribonucleate in 54 patients with polytrauma was conducted. The main/control group consisted of 27/27 patients (21/20 males), aged $39(29 ; 51) / 40(26 ; 53)$ years with the Injury Severity Score of 26(22;34)/25(20;29). Sodium deoxyribonucleate is hydrophilic fragments of native DNA. Randomization: the patients assigned with even numbers were given the study drug of an even batch, those assigned with odd numbers received the drug of an odd batch. Every vial in one batch contained $75 \mathrm{mg}$ sodium deoxyribonucleate, vials of the other batch contained only a solvent. Intramuscular injections were given daily for 10 days starting from the post-injury day. Blood tests assessing red and main population of white cells, CD117+ and CD34+mononuclears, CD14+monocytes and CD14+granulocytes, HLA-DR+ mononuclears, defensin+ neutrophilic granulocytes (NG), IL-6, CRP were made before first injection, on post-injury Days 8 and 15. $\mathrm{Hb}$ and TP were regularly assessed. On post-injury Day 8 counts $(\wedge 109 / \mathrm{L})$ of lymphocytes $(2.36 \pm 0.19 / 1.83 \pm 0.18 ; \mathrm{p}=0.048)$, monocytes $(0.89 \pm 0.007 / 0.69 \pm 0.007 ; \mathrm{p}=0.049), \mathrm{CD} 117+$ $(0.81 \pm 0.07 / 0.44 \pm 0.07 ; \mathrm{p}=0.000)$ and $\mathrm{CD} 34+$ mononuclears $(0.83 \pm 0.07 / 0.65 \pm 0.05 ; \mathrm{p}=0.042)$ increased in patients of the main group as compared to the controls. On post-injury Day 15 the achieved monocyte count increase retained $(0.65 \pm 0.07 / 0.46 \pm 0.05 ; \mathrm{p}=0.033)$, while counts of CD14+monocytes $\quad(0.38 \pm 0.03 / 0.24 \pm 0.02 ; \quad \mathrm{p}=0.041), \quad$ HLA-DR+ mononuclears $(1.34 \pm 0.12 / 1.04 \pm 0.08 ; \mathrm{p}=0.044)$ and defensin $+\mathrm{NG}(42.0 \% \pm 2.4 \% / 34.3 \% \pm 3.7 \% ; \mathrm{p}=0.044)$ increased in patients of the main group as compared to the control one. In both groups the concentrations of IL-6, pg/mL (Day 1 - 115 $\pm 14 / 134 \pm 14$; p=0.343; Day 8 - 51 $\pm 7 / 74 \pm 9$; $\mathrm{p}=0.049$; Day $15-25 \pm 3 / 29 \pm 5 ; \mathrm{p}=0.496$ ) and CRP, $\mathrm{mg} / \mathrm{L}$ (Day $1-69 \pm 6 / 84 \pm 8 ; \mathrm{p}=0.141$; Day 8 - 82 $\pm 13 / 82 \pm 12 ; \mathrm{p}=1.000$; Day 15 - 21 $\pm 4 / 35 \pm 7$; $\mathrm{p}=0.090$ ) equally decreased. The study drug had a positive effect in reducing a hospital stay from 39.6 to 32.8 days, decreasing the number of complications in 1.8 times, and the duration of anemia and hypoproteinemia in 2.5 and 2.4 times respectively.
\end{abstract}

Keywords: polytrauma, bone marrow failure, hematopoiesis, hypoproteinemia, anemia, complications, sodium deoxyribonucleate 


\section{Introduction}

Polytrauma is accompanied by blood loss, extensive tissue damage and systemic inflammation, which create an increased load on the immune and hematopoietic systems due to the loss of part of cellular elements and their subsequent increased need in protection against infection and restoration. The abnormalities listed contribute to the development of complications [1].

Immunity correcting agents which maintain hematopoiesis and protection against infection and, that is crucially, do not enhance inflammation prove to be useful in the treatment of patients with polytrauma. These conditions limit a choice of immunocorrecting agents. Nucleic acid-based drugs that have been used to restore hematopoiesis in patients with radiation sickness, after chemotherapy, and in severe sepsis have a good perspective [2,3].

The maintenance of a native (non-denatured) form of deoxyribonucleate has been established to be of importance for DNA-containing drugs to realize their biological activity. These drugs increase the proliferative activity of bone marrow and the intensity of reticuloendothelial cell activity [2]. However, they have not been studied in patients with polytrauma.

At a cellular level, the regulatory action of DNA is carried out through terminal CpG fragments, which can be either methylated or unmethylated [4]. Sodium deoxyribonucleate, Derinat ${ }^{\circledR}$ contains not less than $50 \%$ of unmethylated ends of all nucleotide chains, being ligands of an endosomal toll-like receptor 9 (TLR9) [5]. It was found in a mice experiment, that topical application of sodium deoxyribonucleate reduced swelling and skin damage within pressure sores. This effect was achieved by inhibiting local oxidative stress caused by tissue ischemia-reperfusion [6].

The study was aimed to evaluate effects of native DNA fragments on hematopoiesis and protection against infection in patients with polytrauma.

\section{Materials and Methods}

Derinat ${ }^{\circledR}$ - a commercial product of sodium deoxyribonucleate - (OOO "FZ Immunolex", Moscow, Russia, Registration No. P N002916/01) is low molecular fragments of native DNA with a molecular weight of $270-500 \mathrm{kDa}$, isolated from the milt of sturgeons. When administered into the body, increased absorption and accumulation of the drug occurs in the 
most actively dividing cells - in bone marrow, the spleen, lymph nodes, the skin and mucous membranes [2].

The study was designed as single-center, prospective, randomized, double-blind, placebocontrolled. The study protocol was approved by the local ethics committee (minutes No.4 on 18.05.2016).

The inclusion criteria for the study were the age of 18 to 70 years, the presence of traumatic shock of II or III severity degrees with a probable mortality rate of less than 50\% (12> ISS < $36[7] ;+7.5>+/-\mathrm{T}<+48[8])$.

The exclusion criteria were sexually transmitted diseases, viral hepatitis, HIV, chronic renal failure, endocrine pathology, chronic diseases requiring the treatment with anti-inflammatory drugs, chronic alcohol or drug addiction, pregnancy.

The study drug and placebo were of different batch parity. Both the study subjects, and the medical staff were blinded to which batch contained the active ingredient. All subjects received $5.0 \mathrm{ml}$ (one vial) of the drug/placebo intramuscularly once daily for 10 days, starting from the post-injury day. The randomization was based on the generation of 60 random numbers. Patients with a randomly assigned even numbers were injected with the drug/placebo of an even batch, those having odd individual numbers received that of an odd batch.

The analysis set included 54 of 60 consecutively enrolled patients with polytrauma (05.2016 05.2018). 27 of these patients were included into the main group - Group I (treated with the study drug) and 27 ones composed the control group - Group II (treated with the placebo). 6 patients were withdrawn from the study due to the transfer to another hospital $(n=3)$, hepatitis $(n=2)$ and pregnancy $(n=1)$.

The severity of injuries sustained was assessed using the ISS scale [7]. A total injury severity and response to it were also evaluated using the Yu.N. Tzybin prognostic formula $(+/-\mathrm{T})$ as the individual prediction of a traumatic shock duration in hours (T) and the probable outcome (+ will survive, - will die) [8]. The complications occurred were considered as life-threatening and non-life-threatening, as well as infectious and non-infectious.

Control laboratory values were obtained when examining 28 apparently healthy adults aged 18-70 years. 
All patients underwent clinical examinations, instrumental and laboratory tests according to the current protocols. In addition, the states of immunity and hematopoiesis were examined before the first injection of the drug and then in 7 and 14 days (1, 8 and 15 post-injury days). Blood cell counts and hemoglobin $(\mathrm{Hb})$ concentrations were assessed (with a hematological analyzer Sysmex XT4000, Japan). Phenotypic and activation markers of blood cells such as relative and absolute counts of cells expressing the stem cell factor receptor CD117 ${ }^{+}(\mathrm{NCL}$ cKIT) and the stem cell adhesion receptor CD34 (RTU- END, Leica Biosystems), CD14 ${ }^{+}$ monocytes and $\mathrm{CD}_{14}{ }^{+}$neutrophilic granulocytes (NCL-CD14), HLA-DR ${ }^{+}$mononuclear cells (NCL-LN3, Leica Biosystems), defensin ${ }^{+}$neutrophilic granulocytes, (human neutrophil peptides, HNP 1-3, Leica Biosystems), ( $\operatorname{Def}^{+} \mathrm{NG}$ ) were immunocytochemically evaluated using an imaging system (Novolink Polymer Detection Systems, UK) and monoclonal antibodies. Blood concentrations of IL-6 (ELISA, Vector-Best, Russia), C-reactive protein (CRP) and total protein (TP) (Cobas 6000, c501, Roche Diagnostic, Switzerland) were also determined. Blood $\mathrm{Hb}$ and $\mathrm{TP}$ concentrations were assessed throughout the entire period of hospitalization. The duration of documented anemia $(\mathrm{Hb}<100 \mathrm{~g} / \mathrm{L}$ and $\mathrm{Hb}<90 \mathrm{~g} / \mathrm{L})$ and hypoproteinemia ( $\mathrm{TP}<60 \mathrm{~g} / \mathrm{L}$ and $\mathrm{TP}<50 \mathrm{~g} / \mathrm{L}$ ) in days were counted for every patient.

Statistical data were processed using the Statistica 10 software package. Descriptive statistics of tables were presented by values of the median and interquartile range, the mean and an error $(\mathrm{M} \pm \mathrm{m})$, as well as the calculation of percentages. Differences in quantitative parameters were evaluated using nonparametric criteria such as a Mann-Whitney test for intergroup comparison and a Wilcoxon test for intragroup one.

\section{Results}

Subjects of both groups did not differ in age, sex, the severity of injury (ISS) and shock $( \pm T)$, the character of the injuries sustained, and the volume of blood transfusion therapy (Table 1).

Table 1.Characterization of patients and treatment results

\begin{tabular}{|c|c|c|}
\hline Indicators & Main group (I) & Control group (II) \\
\hline Number of patients & 27 & 27 \\
\hline Mail, (\%) & $21(78 \%)$ & $20(74 \%)$ \\
\hline Age, years & $39(29 ; 51)$ & $40(26 ; 53)$ \\
\hline
\end{tabular}




\begin{tabular}{|c|c|c|}
\hline Car accident /catatrauma, number & $22 / 5$ & $21 / 6$ \\
\hline Shock II degree (\%) & $17(63 \%)$ & $16(59 \%)$ \\
\hline Shock III degree (\%) & $10(37 \%)$ & $11(41 \%)$ \\
\hline Injury Severe Score, points & $26(22 ; 34)$ & $25(20 ; 29)$ \\
\hline Shock score \pm T, hours & $+12,9(8,7 ; 15,9)$ & $+12,3(9,3 ; 13,8)$ \\
\hline Total blood transfusion volume, 1 & $1,8 \pm 0,3$ & $39,8 \pm 0,3$ \\
\hline The average duration of hospitalization, days & $32,8 \pm 3,0$ & 2 \\
\hline Died & 1 & 14 \\
\hline The number of patients with complications & 13 & 39 \\
\hline The number of patients without complications & 14 & 13 \\
\hline Total number of complications & 21 & 39,8 \\
\hline
\end{tabular}

There were no differences between the groups in the frequency and the dominance of injuries to various parts of the body (Table 2), as well as in the scope of surgical and conservative treatment.

Table 2. Frequency of damage to various parts of the body

\begin{tabular}{|c|c|c|c|c|c|c|}
\hline \multirow{2}{*}{\begin{tabular}{c}
\multirow{2}{*}{$\begin{array}{c}\text { Part of the } \\
\text { body }\end{array}$} \\
\cline { 2 - 7 }
\end{tabular}} & \multicolumn{2}{|c|}{ Total } & \multicolumn{2}{|c|}{ dominant } & \multicolumn{2}{c|}{ competing } \\
\cline { 2 - 7 } & \multicolumn{2}{|c|}{ Group } & \multicolumn{2}{|c|}{ group } & \multicolumn{2}{c|}{ group } \\
\cline { 2 - 7 } & Main (I) & Control (II) & Main (I) & Control (II) & Main (I) & Control (II) \\
\hline Head & $52 \%(14)$ & $67 \%(18)$ & $14,8 \%(4)$ & $7,4 \%(2)$ & $37 \%(10)$ & $14,8 \%(4)$ \\
\hline Chest & $52 \%(14)$ & $52 \%(14)$ & $40,7 \%(11)$ & $44,4 \%(12)$ & $14,8 \%(4)$ & $22,2 \%(6)$ \\
\hline Abdomen & $11 \%(3)$ & $26 \%(7)$ & $7,4 \%(2)$ & $11,1 \%(3)$ & 0 & $11,1 \%(3)$ \\
\hline Pelvis & $33 \%(9)$ & $30 \%(8)$ & $18,5 \%(5)$ & $18,5 \%(5)$ & $7,4 \%(2)$ & 0 \\
\hline Spine & $44 \%(12)$ & $37 \%(10)$ & $3,7 \%(1)$ & 0 & $14,8 \%(4)$ & $7,4 \%(2)$ \\
\hline
\end{tabular}




\begin{tabular}{|c|c|c|c|c|c|c|}
\hline Limbs & $44 \%(12)$ & $44 \%(12)$ & $14,8 \%(4)$ & $14,8 \%(4)$ & $7,4 \%(2)$ & $7,4 \%(2)$ \\
\hline 2 body parts & $15 \%(4)$ & $19 \%(5)$ & 0 & 0 & $14,8 \%(4)$ & $18,5 \%(5)$ \\
\hline $\begin{array}{c}3 \text { or more body } \\
\text { parts }\end{array}$ & $85 \%(23)$ & $81 \%(22)$ & 0 & 0 & 0 & $3,7 \%(1)$ \\
\hline
\end{tabular}

On post-injury day there were no differences in blood hemoglobin $(\mathrm{Hb}, \mathrm{g} / \mathrm{L}-107 \pm 3$ and $104 \pm 4, \mathrm{p}=0.551)$ and total protein $(\mathrm{TP}, \mathrm{g} / \mathrm{L}-56 \pm 1$ and $54 \pm 2, \mathrm{p}=0.189)$ levels, respectively, between subjects of Groups I and II.

Based on the evaluation results of the patients' condition during hospital treatment $17 \%$ of all patients with polytrauma ( $n=5$ in Group I and $n=4$ in Group II) had no complications. $33 \%$ of patients ( $\mathrm{n}=9$ in Group I and $\mathrm{n}=9$ in Group II) had the only anemia and/or hypoproteinemia. $50 \%$ of patients ( $n=13$ in Group I and $n=14$ in Group II) had laboratory findings of both anemia and/or hypoproteinemia and clinical complications.

The results of hematopoiesis and immunity state monitoring are presented in Table 4. On Day 7 lymphocyte and monocyte counts were significantly higher in subjects of Group I (as compared to Group II (control). There were differences in the granulocyte counts in both groups throughout the entire period of observation.

Table 3. The content of the main populations of white blood cells in patients

\begin{tabular}{|c|c|c|c|c|c|c|}
\hline \multirow{2}{*}{$\begin{array}{c}\text { Indicators / } \\
\text { Control level } \\
\text { healthy adults }\end{array}$} & \multirow{2}{*}{$\begin{array}{l}\text { Patient } \\
\text { Groups }\end{array}$} & $\begin{array}{l}\text { Before } \\
\text { introduction }\end{array}$ & After 7 days & After 14 days & \multirow{2}{*}{$\mathrm{P}_{1,2}$} & \multirow{2}{*}{$\mathrm{P}_{1,3}$} \\
\hline & & 1 & 2 & 3 & & \\
\hline $\begin{array}{l}\text { Lymphocytes } \\
1,88 \pm 0,39 \cdot 10^{9} / 1\end{array}$ & $\begin{array}{l}\text { I } \\
\text { II }\end{array}$ & $\begin{array}{c}1,33 \pm 0,09 \\
1,19 \pm 0,11 \\
p=0,329\end{array}$ & $\begin{array}{c}2,36 \pm 0,19 \\
1,83 \pm 0,18 \\
p=0,048\end{array}$ & $\begin{array}{c}2,04 \pm 0,16 \\
1,82 \pm 0,17 \\
p=0,352\end{array}$ & $\begin{array}{l}0,000 \\
0,004\end{array}$ & $\begin{array}{l}0,000 \\
0,003\end{array}$ \\
\hline $\begin{array}{c}\text { Monocytes } \\
0,34 \pm 0,13 \cdot 10^{9} / \text { л }\end{array}$ & $\begin{array}{l}\text { I } \\
\text { II }\end{array}$ & $\begin{array}{c}0,56 \pm 0,05 \\
0,54 \pm 0,06 \\
p=0,799\end{array}$ & $\begin{array}{c}0,89 \pm 0,07 \\
0,69 \pm 0,07 \\
p=0,049\end{array}$ & $\begin{array}{c}0,65 \pm 0,07 \\
0,46 \pm 0,05 \\
p=0,033\end{array}$ & $\begin{array}{l}0,000 \\
0,110\end{array}$ & $\begin{array}{l}0,301 \\
0,311\end{array}$ \\
\hline $\begin{array}{c}\mathrm{NG} \\
0,34 \pm 0,13 \cdot 10^{9} / \text { л }\end{array}$ & $\begin{array}{l}\text { I } \\
\text { II }\end{array}$ & $\begin{array}{l}9,5 \pm 0,6 \\
9,6 \pm 0,7 \\
p=0,914\end{array}$ & $\begin{array}{c}7,0 \pm 0,5 \\
6,9 \pm 0,5 \\
p=0,888\end{array}$ & $\begin{array}{c}5,9 \pm 0,5 \\
5,5 \pm 0,6 \\
p=0,611\end{array}$ & $\begin{array}{l}0,013 \\
0,014\end{array}$ & $\begin{array}{l}0,001 \\
0,002\end{array}$ \\
\hline
\end{tabular}


Note. $\mathrm{p}$ - the significance of differences between the groups of patients of the main and comparisons according to the Mann-Whitney U test.

Note. P - the significance of differences to the Wilcoxon test: $\mathrm{P}_{1,2}$ - between 1 and 2 periods of observation, $\mathrm{P}_{1,3}$ - between 1 and 3 periods of observation $\mathrm{CD} 117^{+}$and $\mathrm{CD} 34^{+}$cell counts were evaluated (Table 4) in order to assess the drug effect on the early stage of hematopoiesis and the related reparative process.

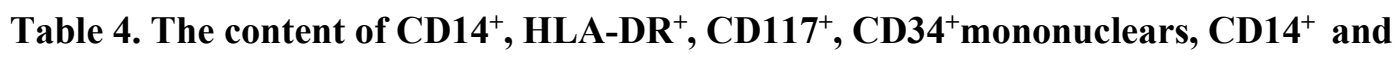
defensin ${ }^{+} \mathrm{NG}$ in the blood of patients

\begin{tabular}{|c|c|c|c|c|c|c|}
\hline \multirow{2}{*}{$\begin{array}{c}\text { Indicators / } \\
\text { Control level } \\
\text { healthy adults }\end{array}$} & \multirow{2}{*}{$\begin{array}{l}\text { Patient } \\
\text { Groups }\end{array}$} & $\begin{array}{l}\text { Before } \\
\text { introduction }\end{array}$ & After 7 days & After 14 days & \multirow{2}{*}{$\mathrm{P}_{1,2}$} & \multirow{2}{*}{$\mathrm{P}_{1,3}$} \\
\hline & & 1 & 2 & 3 & & \\
\hline $\begin{array}{l}\mathrm{CD} 117^{+} \text {mononuclears } \\
0,13 \pm 0,10 \cdot 10^{9} / 1\end{array}$ & $\begin{array}{l}\text { I } \\
\text { II }\end{array}$ & $\begin{array}{c}0,46 \pm 0,05 \\
0,44 \pm 0,08 \\
p=0,833\end{array}$ & $\begin{array}{c}0,81 \pm 0,07 \\
0,44 \pm 0,07 \\
p=0,001\end{array}$ & $\begin{array}{c}0,46 \pm 0,05 \\
0,39 \pm 0,07 \\
p=0,421\end{array}$ & $\begin{array}{l}0,000 \\
1,000\end{array}$ & $\begin{array}{l}0,888 \\
0,640\end{array}$ \\
\hline $\begin{array}{c}\mathrm{CD} 34^{+} \text {mononuclears } \\
0,17 \pm 0,12 \cdot 10^{9} / 1\end{array}$ & $\begin{array}{l}\text { I } \\
\text { II }\end{array}$ & $\begin{array}{c}0,57 \pm 0,04 \\
0,46 \pm 0,04 \\
p=0,058\end{array}$ & $\begin{array}{c}0,83 \pm 0,07 \\
0,65 \pm 0,05 \\
p=0,042\end{array}$ & $\begin{array}{c}0,64 \pm 0,05 \\
0,61 \pm 0,07 \\
p=0,729\end{array}$ & $\begin{array}{l}0,003 \\
0,049\end{array}$ & $\begin{array}{l}0,280 \\
0,070\end{array}$ \\
\hline $\begin{array}{c}\text { CD14 }{ }^{+} \text {monocytes } \\
0,03 \pm 0,01 \cdot 10^{9} / 1\end{array}$ & $\begin{array}{l}\text { I } \\
\text { II }\end{array}$ & $\begin{array}{c}0,29 \pm 0,03 \\
0,27 \pm 0,02 \\
p=0,615\end{array}$ & $\begin{array}{c}0,44 \pm 0,04 \\
0,40 \pm 0,03 \\
p=0,712\end{array}$ & $\begin{array}{c}0,38 \pm 0,03 \\
0,24 \pm 0,02 \\
p=0,041\end{array}$ & $\begin{array}{l}0,041 \\
0,045\end{array}$ & $\begin{array}{l}0,209 \\
0,490\end{array}$ \\
\hline $\begin{array}{c}\text { CD14 }{ }^{+} \text {granulocytes } \\
1,88 \pm 0,20 \cdot 10^{9} / 1\end{array}$ & $\begin{array}{l}\text { I } \\
\text { II }\end{array}$ & $\begin{array}{c}4,5 \pm 0,3 \\
4,3 \pm 0,4 \\
p=0,826\end{array}$ & $\begin{array}{c}3,4 \pm 0,2 \\
3,6 \pm 0,3 \\
p=0,554\end{array}$ & $\begin{array}{c}2,3 \pm 0,2 \\
2,9 \pm 0,4 \\
p=0,348\end{array}$ & $\begin{array}{l}0,029 \\
0,308\end{array}$ & $\begin{array}{l}0,000 \\
0,061\end{array}$ \\
\hline $\begin{array}{c}\text { HLA-DR }^{+} \text {mononuclears } \\
0,92 \pm 0,25 \cdot 10^{9} / 1\end{array}$ & $\begin{array}{l}\text { I } \\
\text { II }\end{array}$ & $\begin{array}{c}1,04 \pm 0,06 \\
0,85 \pm 0,06 \\
p=0,030\end{array}$ & $\begin{array}{c}1,52 \pm 0,08 \\
1,26 \pm 0,13 \\
p=0,096\end{array}$ & $\begin{array}{c}1,34 \pm 0,12 \\
1,04 \pm 0,08 \\
p=0,044\end{array}$ & $\begin{array}{l}0,000 \\
0,006\end{array}$ & $\begin{array}{l}0,030 \\
0,064\end{array}$ \\
\hline $\begin{array}{c}\operatorname{Def}^{+} \mathrm{NG} \\
51,3 \pm 14,4 \%\end{array}$ & $\begin{array}{l}\text { I } \\
\text { II }\end{array}$ & $\begin{array}{l}40,3 \pm 2,6 \\
42,0 \pm 3,0 \\
p=0,382\end{array}$ & $\begin{array}{l}43,4 \pm 2,9 \\
38,1 \pm 3,0 \\
p=0,842\end{array}$ & $\begin{array}{l}42,0 \pm 2,4 \\
34,3 \pm 3,7 \\
p=0,044\end{array}$ & $\begin{array}{l}0,725 \\
0,428\end{array}$ & $\begin{array}{l}0,037 \\
0,165\end{array}$ \\
\hline
\end{tabular}

Note. As for Table 3.

The baseline content of these cells in patients of both groups before the first injection of the drug exceeded the normal value in 3-3.5 times. In 7 days the $\mathrm{CD} 117^{+}$mononuclear cell counts significantly increased in 1.8 times in the patients of Group I as compared to Group II, where 
it remained the same throughout the entire period of observation. The count of CD $34^{+}$mononuclear cells significantly increased in patients of both groups (1.46-fold in Group I and 1.41-fold in Group II) in 7 days. At the same time, their number was significantly higher in Group I patients.

The state of early protection against infection can be assessed by blood CD $14^{+}$monocyte, $\mathrm{CD} 14^{+} \mathrm{NG}$, and HLA-DR ${ }^{+}$mononuclear cell levels, as well as by a degree of $\mathrm{Def}^{+} \mathrm{NG}$ mobilization from bone marrow into the blood. CD14 antigens are expressed as part of the toll-like receptor 4 (TLR4) on membranes of monocytes, macrophages and NG for early recognition of conserved pathogen associated membrane patterns (PAMP). The highly specific recognition of bacterial antigens is associated with the expression of MHC class II antigens - HLA-DR - by macrophages, monocytes, B-cells, and dendritic cells. A bacterial growth-inhibitory activity of NG is largely determined by the presence of type 1-3 $\alpha$ defensins (antimicrobial peptides) in lysosomes, which are involved in bacteria and virus killing [9, 10]. Defensins are detected in myeloid cells starting from the stage of a promyelocyte [9].

Prior to the first drug administration blood $\mathrm{CD} 14^{+}$monocyte levels exceeded the normal in 910 times in both groups (Table 3). In 7 days, their number demonstrated a 1.5-fold increase in both groups. On day 14 there was a significantly higher CD14+ monocyte count in Group I as compared to Group II. CD $14^{+} \mathrm{NG}$ counts gradually decreased in patients of both groups within 14 days, but to a greater extent in Group I. Initially there were no differences between the count of antigen-presenting HLA-DR ${ }^{+}$mononuclear cells and the normal limits in patients of both groups. Their number demonstrated a 1.5-fold increase in both groups in 7 days as compared to the baseline. On day 14 the achieved increase remained in Group I versus to Group II, that indicated an activating effect of the drug on an antigen-presenting function of mononuclear cells.

Prior to the drug administration blood $\mathrm{Def}^{+} \mathrm{NG}$ levels were within reference values in both groups. In Group I there was a slight rise of a relative Def ${ }^{+} \mathrm{NG}$ count throughout 14 days (Table 4), while in patients of Group II a percentage of these cells gradually decreased in the population of granulocytes achieving a significant difference by Day 14 .

Thus, the enhanced migration of hematopoietic progenitor cells $\left(\mathrm{CD} 117^{+}\right.$and $\mathrm{CD} 34^{+}$ mononuclear cells) into the blood as influenced by the drug occurred by Day 7 . The number of cells promoting protection against infection such as $\mathrm{CD}_{1} 4^{+}$monocytes, HLA-DR ${ }^{+}$ mononuclear cells and Def ${ }^{+} \mathrm{NG}$ increased by Day 14 . 
The administration of the study drug was not followed by increased systemic inflammation in the study subjects (Table 5). High Il-6 and CRP concentrations observed in patients of both groups on the post-injury day (Before injection) decreased in the same smooth manner within 14 days.

Table 5. Blood IL-6 and CRP in patients

\begin{tabular}{|c|c|c|c|c|c|c|}
\hline \multirow{2}{*}{$\begin{array}{l}\text { Indicators / } \\
\text { Control level } \\
\text { healthy adults }\end{array}$} & \multirow[t]{2}{*}{ Patient Groups } & $\begin{array}{c}\text { Before } \\
\text { introduction }\end{array}$ & $\begin{array}{l}\text { After } \\
7 \text { days }\end{array}$ & $\begin{array}{l}\text { After } \\
14 \text { days }\end{array}$ & \multirow[t]{2}{*}{$P_{1,2}$} & \multirow[t]{2}{*}{$\mathrm{P}_{1,3}$} \\
\hline & & 1 & 2 & 3 & & \\
\hline $\begin{array}{c}\mathrm{IL}-6, \mathrm{pg} / \mathrm{mL} \\
2,11 \pm 2,84\end{array}$ & $\begin{array}{l}\text { I } \\
\text { II }\end{array}$ & $\begin{array}{c}115 \pm 14 \\
134 \pm 14 \\
p=0,343\end{array}$ & $\begin{array}{c}51 \pm 7 \\
74 \pm 9 \\
p=0,049\end{array}$ & $\begin{array}{c}25 \pm 3 \\
29 \pm 5 \\
p=0,496\end{array}$ & $\begin{array}{l}0,000 \\
0,000\end{array}$ & $\begin{array}{l}0,000 \\
0,000\end{array}$ \\
\hline $\begin{array}{c}\mathrm{CRP}, \mathrm{mg} / \mathrm{L} \\
1,16 \pm 0,66\end{array}$ & $\begin{array}{l}\text { I } \\
\text { II }\end{array}$ & $\begin{array}{c}69 \pm 6 \\
84 \pm 8 \\
p=0,141\end{array}$ & $\begin{array}{c}82 \pm 13 \\
82 \pm 12 \\
p=1,000\end{array}$ & $\begin{array}{c}21 \pm 4 \\
35 \pm 7 \\
p=0,090\end{array}$ & $\begin{array}{l}0,369 \\
0,890\end{array}$ & $\begin{array}{l}0,000 \\
0,000\end{array}$ \\
\hline
\end{tabular}

Note. As for Table 3.

For a more detail study of the drug effectiveness, groups I and II were subdivided into: a) subgroups of patients with clinically significant complications (infectious, non-infectious, life-threatening, non-life-threatening, $\mathrm{n}=13 / 14)$, and $\mathrm{b}$ ) subgroups of patients without clinically significant complications $(n=14 / 13)$.

When comparing the numbers of hematopoietic precursors and cells of anti-infection protection in blood (Fig.1-3 and Table 5) a more pronounced immunity correcting effect of sodium deoxyribonucleate was observed in patients with complications (subgroup Ib vs IIb). By Day 7 after the beginning of drug administration there was a 1.7-fold increase of the $\mathrm{CD} 117^{+}$mononuclear cell count in Subgroup $\mathrm{Ib}$ as compared to their 2-fold decrease in patients of Subgroup IIb ( $\mathrm{p}=0.001)$. By Day 14 the $\mathrm{CD} 34^{+}$mononuclear cell count increased in 1.4 times in Subgroup $\mathrm{Ib}$ and was significantly different from the same parameter in Subgroup IIb ( $\mathrm{p}=0.038)$. There were no significant differences between $\mathrm{CD} 117^{+}$and CD34 ${ }^{+}$ levels in Subgroups Ia and IIa. 

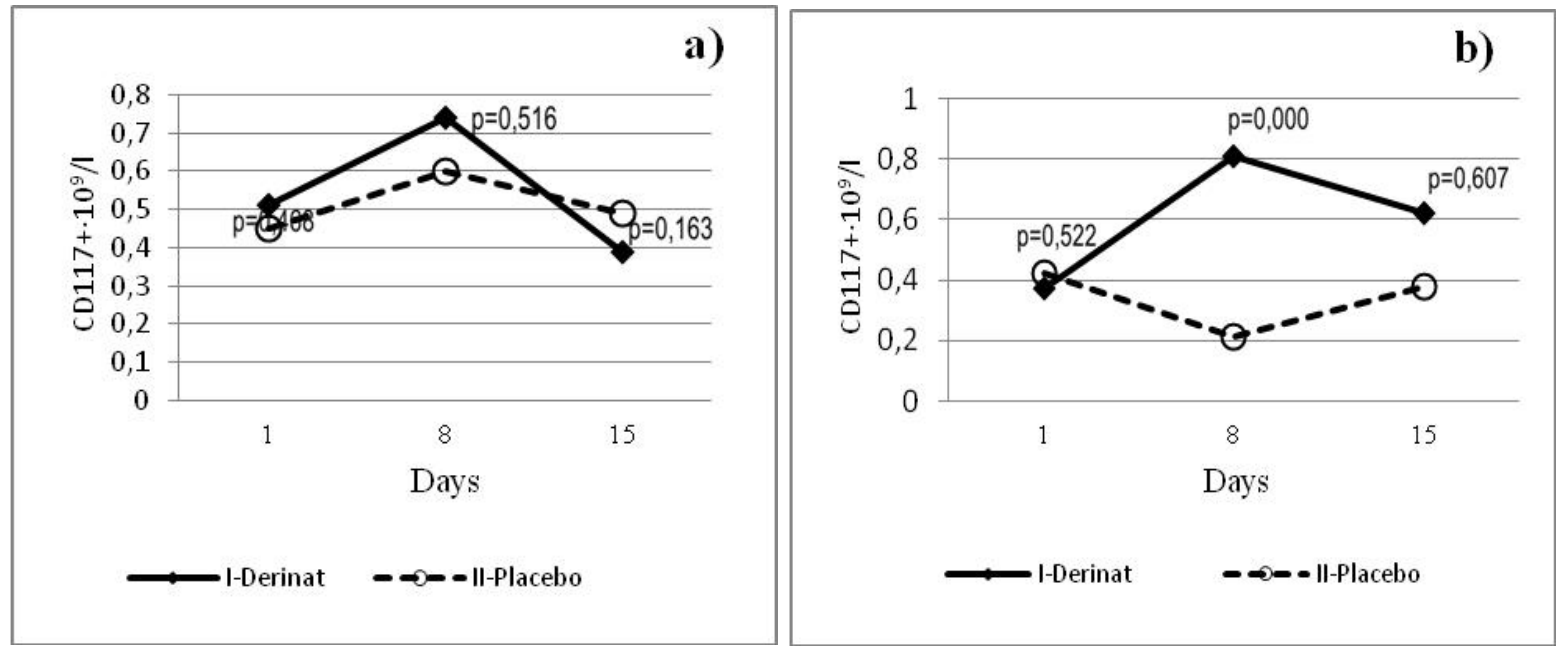

Figura 1. CD117 ${ }^{+}$mononuclear blood (Me) in patients (I-Derinate ws II-Placebo):

a) without complications b) with complications

Note. p- significance of differences according to the Wilcoxon test between subgroups I and II
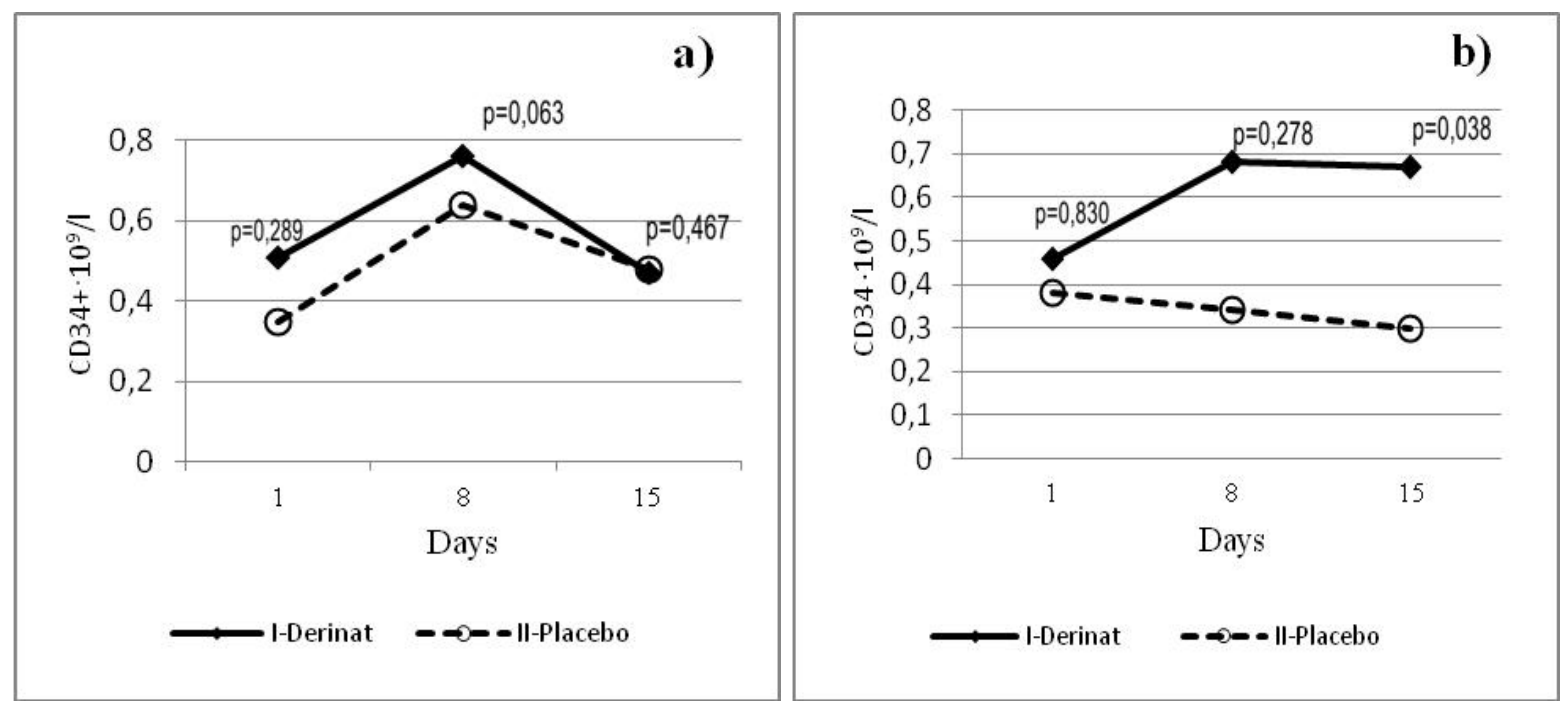

Figura 2. $\mathrm{CD34}^{+}$mononuclear blood (Me) in patients (Derinate ws Placebo):
a) without complications
b) with complications

Note. As for Fig. 1 

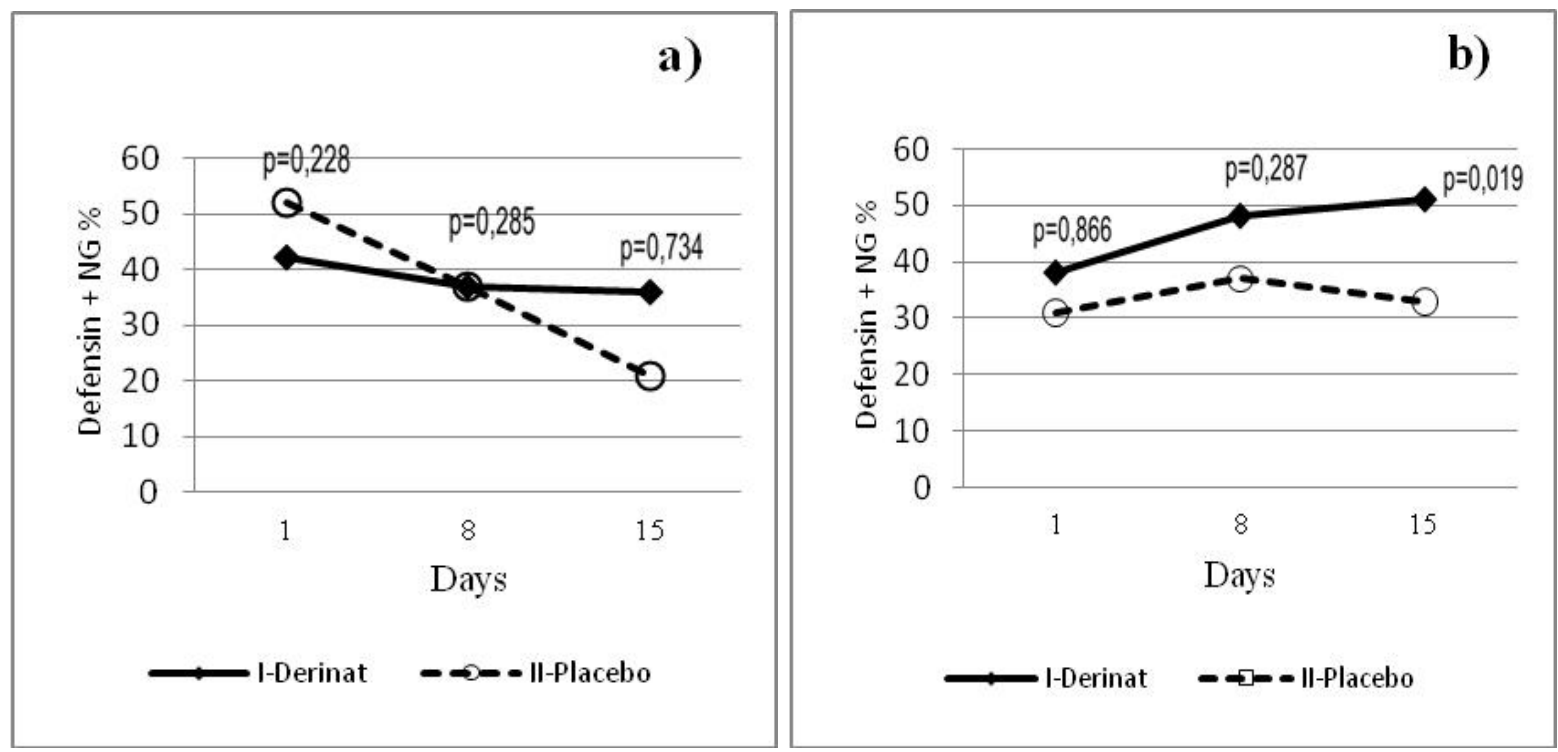

Figure 3. Defensin ${ }^{+}$NG blood (Me) in patients (I-Derinate ws II-Placebo):

a) without complications, b) with complications

Note. As for Fig. 1

Table 6. The content of mononuclear cells CD117+, CD34+ and Def + NG in the blood of patients with different course of polytrauma

\begin{tabular}{|c|c|c|c|c|c|}
\hline $\begin{array}{c}\text { Indicators / } \\
\text { Control level } \\
\text { healthy adults }\end{array}$ & $\begin{array}{c}\text { a) with } \\
\text { complications } \\
\text { b) without } \\
\text { complications }\end{array}$ & $\begin{array}{l}\text { Patient } \\
\text { Groups }\end{array}$ & $\begin{array}{c}\text { Before } \\
\text { introduction }\end{array}$ & $\begin{array}{l}\text { After } \\
7 \text { days }\end{array}$ & $\begin{array}{l}\text { After } \\
14 \text { days }\end{array}$ \\
\hline \multirow{2}{*}{$\begin{array}{c}\mathrm{CD} 117^{+} \text {mononuclears } \\
0,13 \pm 0,10^{\wedge} 10^{9} / 1\end{array}$} & a) & $\begin{array}{l}\text { I } \\
\text { II }\end{array}$ & $\begin{array}{c}0,48 \pm 0,06 \\
0,42 \pm 0,07 \\
p=0,522\end{array}$ & $\begin{array}{c}0,81 \pm 0,09 \\
0,21 \pm 0,13 \\
p=0,000\end{array}$ & $\begin{array}{c}0,68 \pm 0,08 \\
0,44 \pm 0,11 \\
p=0,607\end{array}$ \\
\hline & b) & $\begin{array}{l}\text { I } \\
\text { II }\end{array}$ & $\begin{array}{c}0,49 \pm 0,06 \\
0,40 \pm 0,05 \\
p=0,468\end{array}$ & $\begin{array}{c}0,74 \pm 0,11 \\
0,60 \pm 0,10 \\
p=0,356\end{array}$ & $\begin{array}{c}0,55 \pm 0,07 \\
0,42 \pm 0,07 \\
p=0,206\end{array}$ \\
\hline \multirow{2}{*}{$\begin{array}{c}\text { CD34 } 4^{+} \text {mononuclears } \\
0,17 \pm 0,12^{\wedge} 10^{9} / 1\end{array}$} & a) & $\begin{array}{l}\text { I } \\
\text { II }\end{array}$ & $\begin{array}{c}0,48 \pm 0,06 \\
0,46 \pm 0,07 \\
p=0,830\end{array}$ & $\begin{array}{c}0,66 \pm 0,07 \\
0,51 \pm 0,09 \\
p=0,278\end{array}$ & $\begin{array}{c}0,66 \pm 0,08 \\
0,41 \pm 0,10 \\
p=0,038\end{array}$ \\
\hline & b) & $\begin{array}{l}\text { I } \\
\text { II }\end{array}$ & $\begin{array}{c}0,51 \pm 0,07 \\
0,41 \pm 0,06 \\
p=0,289\end{array}$ & $\begin{array}{c}0,82 \pm 0,07 \\
0,64 \pm 0,06 \\
p=0,063\end{array}$ & $\begin{array}{c}0,51 \pm 0,05 \\
0,60 \pm 0,11 \\
p=0,467\end{array}$ \\
\hline $\begin{array}{c}\operatorname{Def}^{+} \mathrm{NG} \\
51,3 \pm 14,4 \%\end{array}$ & a) & $\begin{array}{l}\text { I } \\
\text { II }\end{array}$ & $\begin{array}{c}35 \pm 3 \\
34 \pm 6 \\
p=0,866\end{array}$ & $\begin{array}{c}45 \pm 5 \\
38 \pm 4 \\
p=0,287\end{array}$ & $\begin{array}{c}43 \pm 4 \\
34 \pm 4 \\
p=0,019\end{array}$ \\
\hline
\end{tabular}




\begin{tabular}{|c|c|c|c|c|}
\hline & & $42 \pm 6$ & $33 \pm 3$ & $34 \pm 3$ \\
b) & I & $51 \pm 5$ & $39 \pm 4$ & $31 \pm 6$ \\
& II & $p=0,228$ & $p=0,285$ & $p=0,734$ \\
\hline
\end{tabular}

Note. $\mathrm{p}$ - the significance of the difference between the groups of patients of the main and comparison according to the Mann-Whitney U-test.

A decreased percentage (\%) of granulocytes with peptides-defensins (Def $\left.{ }^{+} \mathrm{NG}\right)$, appeared to be a specific characteristic of patients with polytrauma. Patients treated with the study drug (Subgroups Ia and $\mathrm{Ib}$ ) had a tendency towards a steady increase of a percentage of these cells (\%) within 14 days, with a more evident rise observed in Subgroup Ib (patients with complications). In patients receiving the placebo \% of $\mathrm{Def}^{+} \mathrm{NG}$ almost did not decrease in those without complications (Subgroup IIa) and dramatically dropped in patients with complications (Subgroup IIb) within 14 days.

A general clinical evaluation of using the study drug in complex therapy of patients with polytrauma revealed that the duration of in-hospital treatment was 6.8 days shorter and amounted to 32.8 days in Group I patients treated with sodium deoxyribonucleate, while it was 39.6 days in Group II receiving the placebo.

The comparison of the number and severity of complications (Subgroups $\mathrm{Ib}$ and $\mathrm{IIb}$ ) demonstrated a significant positive effect of sodium deoxyribonucleate (Table 7).

Table 7. The effect of sodium deoxyribonucleate on the duration of anemia, hypoproteinemia and the number of complications

\begin{tabular}{|c|c|c|c|}
\hline \multirow[b]{2}{*}{ Indicators / Complications } & \multicolumn{2}{|c|}{ Patients with complications } & \multirow[b]{2}{*}{$\mathrm{p}$} \\
\hline & Main subgroupe (Ib) & $\begin{array}{l}\text { Control subgroupe } \\
\text { (IIb) }\end{array}$ & \\
\hline $\begin{array}{l}\text { Blood hemoglobin }<100 \mathrm{~g} / \mathrm{L} \text {, days } \\
\text { Blood hemoglobin }<90 \mathrm{~g} / \mathrm{L} \text {, days }\end{array}$ & $\begin{array}{l}7,1 \pm 2,1 \\
3,2 \pm 1,3\end{array}$ & $\begin{array}{c}16,0 \pm 3,1 \\
7,9 \pm 2,1\end{array}$ & $\begin{array}{l}0,026 \\
0,044\end{array}$ \\
\hline $\begin{array}{l}\text { Total proteins }<60 \mathrm{~g} / \mathrm{L} \text {, days } \\
\text { Total proteins }<50 \mathrm{~g} / \mathrm{L} \text {, days }\end{array}$ & $\begin{array}{l}8,2 \pm 2,2 \\
1,1 \pm 0,5\end{array}$ & $\begin{array}{c}19,5 \pm 4,1 \\
5,4 \pm 1,6\end{array}$ & $\begin{array}{l}0,034 \\
0,009\end{array}$ \\
\hline All complications in 1 patient & $1,6 \pm 0,3$ & $3,0 \pm 0,4$ & 0,014 \\
\hline -life-threatening infectious in 1 patient & $0,8 \pm 0,2$ & $0,7 \pm 0,3$ & 0,579 \\
\hline - non-life-threatening infectious in 1 patient & $0 \pm 0$ & $0,9 \pm 0,3$ & 0,044 \\
\hline -life-threatening non infectious in 1 patient & $0,1 \pm 0,1$ & $0,3 \pm 0,2$ & 0,511 \\
\hline -non life-threatening non infectious in 1 patient & $0,7 \pm 0,2$ & $1,2 \pm 0,2$ & 0,186 \\
\hline
\end{tabular}


Note. $\mathrm{p}$ - the significance of differences between the groups of patients of the main and comparisons according to the Mann-Whitney U test.

The use of the drug contributed to a 1.8-fold decrease of a total number of complications, mainly due to infectious non-life-threatening ones in patients of Subgroup Ia, when compared with patients of Subgroup IIa. Moreover, the duration of anemia (2.3-2.5-fold) and hypoproteinemia (2.4-4.9-fold) decreased in patients of Subgroup Ia as compared to patients of Subgroup IIa.

It should be noted that based on physical examination of sites of injury there were no signs of more active inflammation in these areas in patients of Group I versus Group II. No other adverse effects of the study drug were observed.

\section{Discussion}

Extensive injuries including mechanical trauma result in intensive migration of cells from bone marrow including stem cells which are essential to restore tissue cellular elements, to enhance protection against infection and for reparative processes. The level of bone-marrow hematopoiesis activation, reparative activity and repopulation of hematopoietic stem cells can be evaluated by counts of blood circulating mononuclear cells expressing the stem and mast cell factor receptor CD117 (SCFR, tyrosine kinase Kit) and the stem cell adhesion receptor CD34 [11,12]. The number of blood circulating monocytes and mature granulocytes and their ability to activation reflect the competence of bone-marrow hematopoiesis in polytrauma.

The use of native DNA fragments in patients with polytrauma had a positive effect in increasing the number of blood mononuclear cells expressing a receptor of the stem and mast cell growth factor CD117 and the stem cell adhesion receptor CD34 (Table 3), that indicated the enhanced migration of stem cells into the bloodstream. A peak of this effect was observed in 7 days after the drug injection was started.

In healthy adults about a half of NGs is known to contain anti-microbial type 1-3 $\alpha$-defensine peptides in lysosomes, that lyze microorganisms intra- and extracellularly. In polytrauma a rate of phagocyte anti-infection "response" is of special importance due to the easy penetration of infection through damaged cover tissues and the translocation of endogenous microflora from mucous membranes into the blood when the hemodynamics is compromised and tissue hypoxia occurs [13]. The patients treated with the study drug had a significantly 
increased percentage (\%) of the Def ${ }^{+} \mathrm{NG}$ content, while it progressively decreased in those who received the placebo (Table 3).

Acute anemia and hypoproteinemia are consequential to severe injury and massive blood loss. The use of sodium deoxyribonucleate contributed to a reduced duration of posttraumatic anemia and hypoproteinemia (Table 6). This is crucial to ameliorate adverse effects of tissue and hemic hypoxia, increased blood protein concentration as well as to restore a blood antimicrobial potential and to activate reparative processes in tissues.

Study results demonstrated that the quality of treatment of patients with polytrauma can be improved when bone-marrow hematopoiesis is additionally activated. The complication rate was in 1.8 times lower in the patients treated with sodium deoxyribonucleate than in those who received the placebo.

The immunocorrecting action of sodium deoxyribonucleate is related to the presence of methylated and unmethylated $\mathrm{CpG}$ (cytosine-phosphate-guanine) deoxynucleotides in native DNA fragments. Both types of $\mathrm{CpG}$ deoxynucleotides can exert an activating effect on innate immunity responses. Having penetrated inside a cell unmethylated $\mathrm{CpG}$ motifs activate the expression of TLR-9 on membranes of monocyte, macrophage, B- and dendritic cell endosomes [5, 14,15,16]. Constitutively this receptor is expressed only by B-cells and plasmacytoid dendritic cells (pDC) [4]. Methylated $\mathrm{CpG}$ deoxynucleotides are also capable of inducing the activation of immune cells, however, other signaling pathways are involved in this process [17]. As unmethylated CpG motifs of fragmented DNA are similar to PAMP of microorganisms, they are recognized as antigens. As a result, intracellular signaling pathways are activated, a cell's antigen-presenting capacity is increased, and the production of microbicidal factors and cytokines enhanced [15]. Activated immunocompetent cells induce a secondary activation of cellular and humoral immunity, phagocytosis and increase the production of hemopoietins. That is, all cells of the immune system can be activated after the interaction - direct or by co-stimulation - with CpG-DNA [18].

The sodium deoxyribonucleate ability to increase levels of some proinflammatory agents has been revealed in an experiment. According to the findings of T.V. Rusinova [19] Derinat ${ }^{\circledR}$ enhanced the production of IL- 8 and IFN- $\alpha$ by blood cells of healthy subjects and patients with acute inflammatory nasopharyngeal diseases in vitro. By contrast, J.Liu et al. [6] observed its anti-inflammatory effect when applied on the area of experimental pressure sores, manifested as the inhibition of an IL- $6 \alpha$-receptor within a pressure sore. 
Clinical study results demonstrated that the administration of Derinat ${ }^{\circledR}$ did not increase local and systemic inflammation in patients with different courses of polytrauma (Table 4). Daily administration of the drug to patients with polytrauma starting from post-injury Day 1 to Day 10 activated the migration of hematopoietic progenitor cells from bone marrow into the bloodstream and enhanced the body resistance to infection by increasing counts of antimicrobial peptides-containing neutrophilic granulocytes, monocytes expressing lipopolysaccharide-recognizing antigens $\left(\mathrm{CD} 14^{+}\right)$and mononuclear cells with antigenpresenting membrane complexes (CD HLA-DR ${ }^{+}$.

Sodium deoxyribonucleate had most immunity-correcting effects in patients with complicated polytrauma. Moreover, a 10-day administration of the drug reduced the duration and intensity of post-traumatic hypoproteinemia and anemia. A positive clinical effect of sodium deoxyribonucleate manifested in a reduced hospital stay and a decreased number of complications.

\section{Refences}

[1] Tulupov A.N. Severe concomitant injury. [Tyazhelaya sochetannaya travma]. SaintPetersburg: OOO «RA «Russkiy Yuvelir», 2015. [Rus]

[2] Kaplina E. N., Vaynberg Yu. P. Derinat is a natural immunomodulator for children and adults. 3rd ed., rev. and corr. [Derinat - prirodnyy immunomodulyator dlya detey i vzroslykh. 3-ye izd., per. i ispr.]. M.: "Nauchnaya kniga", 2007. [Rus].

[3] Gromov M. I., Pivovarova L. P. Use of immunomodulator derinat in treatment of surgical patients with severe sepsis. Fundamental research, 2012; 7 (2): 289-295. [Rus]. URL: http://www.fundamental-research.ru/ru/article/view?id=30127 Epub 2020 Dec 17

[4] Vollmer J., Weeratna R.D., Jurk M., Samulowitz U., Mccluskie M.J., Payette P., Davis H.L., Schetter C., Krieg A.M. Oligodeoxynucleotides lacking CpG dinucleotides mediate Toll-like receptor 9 dependent $\mathrm{T}$ helper type 2 biased immune stimulation. Immunology, 2004, Vol. 113, no.2, pp. 212-223. https://www.sciencedirect.com/science/article/pii/S0169409X09000039?via\%3Dihub

[5] Filatov O.Yu., Kashaeva O.V., Bugrimov D.Yu., Klimovich A.A. Morphophysiological principles of the immunological action of eukaryotic DNA. Russian Immunological Journal, 2013; $16(4)$ : 385-390. [Rus]. elibrary.ru/download/elibrary_22390937_46334206.pdf 
[6] Liu J., Rybakina E.G., Korneva E.A., Noda M. Effects of Derinat on ischemiareperfusion-induced pressure ulcer mouse model. Journal of Pharmacological Sciences, 2018 ; 138(2):

123-130.

https://www.sciencedirect.com/science/article/pii/S1347861318301804?via\%3Dihub

[7] Baker S.P., O’Neill B., Haddon W., Long W.B. The Injury Severity Score: a method for describing patients with multiple injuries and evaluating emergency care. J Trauma, 1974; 14(3): 187-196. https://journals.lww.com/jtrauma/Citation/1976/11000/THE_INJURY_SEVERITY_SCO RE_AN_UPDATE.6.aspx

[8] Tsybin Yu.N. A multivariate assessment of the severity of traumatic shock in a clinic. Grekov's Bulletin of Surgery, 1980; 125(9): 62-67.

[9] Ganz T. Defensins: Antimicrobial peptides of innate immunity. Immunology, 2003; 3(9): 710-72. doi: $10.1038 /$ nri1180

[10] Sechet E., Telford E., Bonamy C., Sansonetti Ph.J., Sperandio B. Natural molecules induce and synergize to boost expression of the human antimicrobial peptide $\beta$-defensin- 3 . PNAS, 2018; 115(42): E9869-E9878. doi: 10.1073/pnas.1805298115

[11] Edling C.E., Hallberg B. C-Kit- a hematopoietic cell essential receptor tyrosine kinase. Int J Biochem Cell Biol, 2007; 39: 1995-1998. https://www.sciencedirect.com/science/article/pii/S1357272507000167?via\%3Dihub

[12] Maillard L., Sanfilippo S., Domenech C., Kasmi N., Petit L., Jacques S., Delezoide A., Guimiot F., Eladak S., Moison D., Nicolas N., Rouiller-Fabre V., Pozzi-Godin S., Mennesson B., Brival M., Letourneur F., Jaffredo T., Chomienne C., Souyri M. CD117hi expression identifies a human fetal hematopoietic stem cell population with high proliferation and self-renewal potential. Haematologica $2020 ; 105(2)$ : e43-e47. doi: $\underline{10.3324 / \text { haematol.2018.207811 }}$

[13] Malyshev ME, Pivovarova LP, Ariskina OB, Osipova IV. Post-traumatic anemia in patients with severe mechanical injury. Emergency Medical Aid, 2013; 14(4): 41-47. [Rus]. https://www.elibrary.ru/download/elibrary_18792944_50127236.pdf

[14] Bell E., Curry E.W., Megchelenbrink W., Jouneau L., Brochard V., Tomaz R.A., Mau K.H.T., Atlasi Y., de Souza R.A., Marks H., Stunnenberg H.G., Jouneau A., Azuara V. Dynamic CpG methylation delineates subregions within super-enhancers selectively decommissioned at the exit from naive pluripotency. Nat Commun, 2020;11(1):1112. doi: 10.1038/s41467-020-14916-7. 
[15] Hanagata N. CpG oligodeoxynucleotide nanomedicines for the prophylaxis or treatment of cancers, infectious diseases, and allergies Int J Nanomedicine, 2017; 12: 515-531. doi: 10.2147/IJN.S114477

[16] Polovinkina V.S., Markov E.Yu. The structure and immunoadjuvant properties of CpGDNA. Medical Immunology, 2010; 12(6): 469-476. [Rus]. https://www.elibrary.ru/download/elibrary_15285474_53358590.pdf

[17] Goerdt S. Orfanos C.E. Other functions, other genes: alternative activation of antigenpresenting cells. $\quad$ Immunity, 1999; (10): 137-142. https://www.sciencedirect.com/science/article/pii/S107476130080014X?via\%3Dihub

[18] Ballas Z.K. Modulation of NK cell activity by $\mathrm{CpG}$ oligodeoxynucleotides. Immunologic Research, 2007; 39(1-3): 15-21. https://www.ncbi.nlm.nih.gov/pubmed/17917052

[19] Rusinova T.V. The mechanism of influence of nucleic acid preparations on the production of pro-inflammatory cytokines in vitro in the norm and in the infectious process. Modern problems of science and education, 2016; (3): 11-14. [Rus]. https://www.science-education.ru/ru/article/view?id=24465 